\title{
Teacher Educators' Preparedness to Train Teachers of Literacy in Selected Primary Colleges of Education in Zambia
}

\author{
Gwen Mutolwa* \\ The University of Zambia, Zambia
}

*Corresponding Author: Gwen Mutolwa, The University of Zambia, Zambia

\begin{abstract}
The issue of literacy in Zambia has been a subject of concern due to the continued low literacy levels among Zambian pupils. Literacy should be the main focus if any improvement in the education system is to be done. Therefore, the focus of literacy education is to improve the reading and writing skills of learners which should begin with teacher preparation. The literacy and language lecturer, who is equally an important factor in explaining the quality of teacher training and teacher graduates who eventually go to teach literacy in primary schools has been ignored in the literacy research agenda. The purpose of this study was to establish whether Literacy and Language lecturers were adequately prepared to train teachers in literacy and language education in selected primary colleges of education in Zambia. The objectives of the study were to establish the preparedness of college lecturers to train teachers in literacy and language education and identify challenges which lecturers face in preparing teachers in literacy and language education. The study employed a mixed method convergent parallel design which involved both qualitative and quantitative methods. A purposive sampling technique was used to come up with 49 respondents, that is, 45 college lecturers and four college administrators while simple random sampling was used to select colleges of education where data was collected. Data was collected through questionnaires and interviews. Qualitative data collected through interviews was organized guided by research questions. Quantitative data was analysed using the Statistical Package for Social Sciences (SPSS) version 20 to generate descriptive statistical information in form of frequencies as well as percentages. The study found that while all lecturers were professionally trained either as primary school teachers or secondary school teachers, they were not fully prepared to train teachers in literacy and language education. This was due to the failure to interpret the teacher education programme, the teacher education curriculum not being totally in line with the school curriculum in most areas of literacy and language education and failure by the ministry of general education to update college lecturers on the latest developments in the primary school curriculum and shortage of lecturers were among the challenges. The study recommended that college lecturers need to be inducted and mentored upon appointment in order to prepare them to train teachers, College curriculum should always be updated in line with the school curriculum in order for colleges of education to prepare students effectively, and there is need to engage literacy and language lectures in the formulation and /or revision of literacy policies.
\end{abstract}

Keywords: Teacher Education, Literacy, Literacy and Language Lecturers, Teachers

\section{INTRODUCTION}

The quality and effectiveness of an education system depends heavily on the quality of its teachers. They are the key persons in determining the success in meeting the education systems goals. The education and wellbeing of school children depends heavily on the competence, commitment and resourcefulness of teachers (Mwanza, 2016). The quality of teachers depends on the training which they undergo. Training and professional development therefore, underpin what a teacher can accomplish in a school. The quality of teachers therefore is determined by the teacher education regiment experience that a prospective teacher goes through (Luangala and Mulenga, 2015). According to Zientek (2007) teacher quality is the responsibility of teacher education. Therefore, the teaching and learning of teacher education students is critical in building teacher candidates' capacity to improve learners' output. Teacher educators need to be knowledgeable and ready to take over the responsibility of training teachers. It is therefore important to note that the goal of teacher education programme is to produce effective teachers. This can lead to effective teaching and learning in schools. 
The European Commission (2013) also acknowledged that teacher educators are crucial players for maintaining and improving the high quality of the teaching workforce. They have a significant impact upon the quality of teaching and learning in schools. Yet they are often neglected in policy-making. In order to successfully train teachers, teacher educators should be well trained and supported and be able to tailor the curriculum to the needs of the students. This means that once teacher educators have pedagogical and content knowledge, they will be able to effectively train teachers. UNESCO (2014) added that an equally important issue is the ability of the training apparatus, lecturers, to effectively equip future teachers and those already in class with the required professional skills and competencies to teach effectively. It is often said that the quality of an educational system cannot be greater than the quality of its teachers, and yet often not much attention is paid to understanding how systems that produce teachers can be made more effective to impact on learning outcomes (Bunyi, Wangia, Magoma and Limboro, 2013).

The Ministry of General Education (MoGE), revised the language-in- education policy and it effected the use of familiar Zambian languages best known to a learner, as language of learning as well as language for teaching initial literacy from Grades one to four. English Language was introduced as a subject at Grade two, while it was going to be the Language of instruction from Grade 5 to tertiary education (ZECF 2013). Since the curriculum was revised from early childhood to tertiary education, it implied that Zambian Languages were to be offered as subjects at both primary and secondary schools, while Colleges of Education would prepare teachers in line with requirements of the reviewed 2013 curriculum. However, the issue of literacy in Zambia has, for some time been a subject of concern due to the low literacy levels observed among Zambian pupils, particularly among pupils in public primary schools. The Ministry of Education (2013) suggested that dedicated training in literacy instruction during teacher pre-service, a curriculum focused on literacy instruction and continued support to teach reading through in-service training, a focus on developing primary language skills as well as parental and community support around reading instruction may constitute some areas where we have faltered. This meant that the ministry of education noted that literacy levels were not improving among learners in schools and they tried to find ways of improving them. However, many educational policies concerning literacy in Zambia are implemented in schools leaving out the teacher educators, particularly the literacy and language teacher educators.

\subsection{Aim of the Study and Research Objectives}

The aim of the study was to establish literacy and language education lecturers' preparedness to train teachers in literacy and language education in selected primary colleges of education in Zambia. The study sought to: a. establish the preparedness of college lecturers to train teachers in literacy and language education; and b. identify challenges which literacy and language lecturers faced in training teachers in literacy and language education.

\section{LITERATURE REVIEW}

This section reviews some studies that have been conducted on lecturers' preparedness to train teachers in literacy and language education as well as challenges which literacy and language education lecturers face when training teachers in literacy and language education. Perraton (2015) states that teacher education includes four elements, which are improving the general educational background of the trainee teachers (initial teacher training), increasing their knowledge and understanding of the subjects they are to teach, pedagogy and understanding of children and learning (induction), and the development of practical skills and competences. Colleges of education are of great importance as they are meant to equip primary school teachers with habits of thought, dispositions, actions, skills, knowledge and attitudes that would make them effective teachers (Cruickshank and Metcalf, 1990). The Ministry of Education (1977: 67) equally noted that teacher education should assist the teacher to develop his planning and instructional skills through the use of a variety of techniques and teaching methods. When literacy and language education lecturers use a variety of techniques and teaching methods, students are exposed such that it can be easier for them to apply the same methods and techniques when teaching in literacy schools. This shows that teacher educators should themselves be knowledgeable about the methods needed to train teachers so that they impart what is necessary in the students. Ball and McDiarmid (2010) reported that recent research which focused on the ways in which teachers and teacher candidates understood the subjects 
that they taught revealed that teachers often had gaps in knowledge and skills similar to those of their pupils. The skills imparted in the students are meant to enhance their teaching skills once they are deployed. This means that the lecturers themselves are supposed to be equipped with the skills necessary for teacher training. It is through this process that teacher trainers equip teachers with the necessary pedagogical skills and knowledge. Therefore, it is important that the literacy and language education lecturers from primary colleges of education should not only have the right qualifications in order to train primary school teachers but should also have the necessary skills and knowledge required to train primary school teachers. According to Korthagen, Loughran and Russell (2006), teacher education programmes are increasingly being criticised for their lack of linkage to student teachers' needs and for their little impact on practice. Literacy and language lecturers therefore need to be knowledgeable and ready to take the responsibility of training teachers. Improving teacher education means improving teacher educators as well as teacher education programmes. This is in line with UNESCO (2011) which stated that reaching teacher trainees also have to involve building the knowledge and skills of teacher trainers. They are gatekeepers as well as role models and a source of intellectual leadership for trainee teachers. Effective interventions will give teacher trainers access to new content knowledge, research skills, teaching methodologies and the opportunity to make a much greater impact on generations of new teachers entering the profession. Literacy and language lecturers should have adequate knowledge in order to train teachers effectively.

It is believed that quality teachers are products of quality training which emanates from quality teacher educators. This means that literacy and language lecturers in colleges of education training teachers should be competent both in content and methodology. They need to understand what teaching and learning is about including what can help students acquire the various methods. They also need be conversant with the primary school curriculum so that they train competent and skillful teachers. Literacy and language lectures should also have the right qualifications in order to effectively train teachers. The Ministry of Education (2013) stated that teacher training institutions in Zambia should ensure that they put in place the right numbers with correct academic and professional qualifications for teaching and non-teaching staff. This will help in the effective implementation of the curricula at different levels.

Various studies have been done concerning lecturer preparedness to train teachers in literacy and language education and challenges which lecturers face when training teachers. Mutemeri (2010) conducted a study in South African universities to examine how teacher educators in South African universities prepared teacher education students for teaching and learning within the context of quality. It can therefore be concluded that there were so many factors such as curriculum imbalance and curriculum coherence which were observed to lecturers' failure to prepare students as expected. This means that lecturers themselves were not adequately prepared to train teachers because of so many hurdles such as methodology, curricular imbalance and coherence. It was found out that there was a general gap between theory and practice in teacher education. There was little connection between what student teachers learned in university classes and the practicalities of teaching in schools. This clearly indicates that teacher educators had no knowledge about what was taught in schools and trained teachers contrary to what they would find in schools.

According to Britzman (2003), the disconnection between the field and on-campus components of pre-service programmes can result in a devaluing by pre-service teachers of their theoretical learning. This mismatch between the college curriculum and the school curriculum can also lead to lack of preparedness by lecturers which can in turn lead to ineffective preparation of teachers. This was also observed by Chella (2015) who concluded that majority trainee teachers were not well prepared to teach initial literacy and this was as a result of teacher trainers not having the necessary literacy skills and knowledge. Kombe (2017) in her study on whether teachers were adequately prepared to implement the 2014 revised literacy policy found out that teachers were finding it difficult to implement the teacher education programme because they did not fully understand the content of the 2014 revised policy. She also found out that colleges of education were finding it challenging to comprehensively revise the teacher education programme because they did not fully understand the content of the 2014 revised policy. The current study focused on the lecturer preparedness to train teachers in literacy and language education. Though the two studies focused on trainee teachers and teachers respectively, it can be note that the aspect of lecturer preparedness also came out because they are the trainers of teachers. 
Although the study by Changwe (2017) was conducted in mathematics, it aimed at investigating whether the teacher education programme at the University of Zambia (UNZA) adequately prepared student teachers in secondary mathematics content and pedagogical knowledge for teaching classroom mathematics in Zambian secondary schools. Changwe (2017) found out that UNZA mathematics teacher education curriculum did not adequately prepare student teachers to teach mathematics. $\mathrm{He}$ concluded that one of the reasons was that mathematics content and methods was taught by lecturers who have never taught before in secondary schools who had no idea about secondary school teaching and therefore were preparing students contrary to secondary mathematics teaching. This led to the inappropriate teaching by the graduands and poor mathematics performance in secondary schools. This shows that the lecturers were not prepared to train teachers in mathematics because they had no idea about what was being taught in secondary school.

Although different studies on the challenges faced by lecturers when training teachers have been conducted, none has focused on the challenges faced by lecturers of literacy and language education. The Ministry of Education (1992) listed the following as quality-related problems in the colleges: An overloaded and inappropriate curriculum; promotion of rigid teacher-centered methodologies; an excessively demanding examinations system; staff with inadequate or unsuitable educational and professional qualifications; and shortage of educational resources of all kinds. The constant changes made to the primary school curriculum need constant updates to colleges of education as well. Sinkinson (1997) indicated that new lecturers faced some challenges as they received little or no support on guidance on lecturing, research, time management, and there was no formalized structures of induction though some admitted having received informal induction from more experienced lecturers within the department. This was after conducting a research in six schools of education in universities involving 14 lecturers with a minimal of 6 years prior to the appointment to new posts. The study recommended that there was need for effective induction of new lecturers in education in order to overcome some of the challenges. MOE (1996:115) stated that, "teacher education is a continuing process that must be extended throughout the individual's years of actual teaching". This is so because the curriculum keeps on changing and teachers move from one level to the next. There is need therefore to keep on learning new methods and techniques which come with the changes that take place in the education sector.

Mabale (2012) conducted a study on the challenges faced by lecturers in the implementation of the National Certificate Vocational (NCV) curriculum at Mopani South East FET College. He sampled two campuses with three lecturers from each campus and collected data through interviews and document analysis. He found out that lecturers faced challenges when it came to implementing the curriculum. Among the findings was that while some teaching materials were available, other resources such as internet access, reference and research materials needed by lecturers were not available. Other challenges lecturers faced were overcrowded classrooms and unprepared students. Some lecturers were using the initial training qualifications which they thought was not enough to impart the curriculum. This is what Ridge (2014) also observed that some of the lecturers lacked adequate knowledge of pedagogy and lacked hands-on contact with the exigencies of teaching in schools. The Ministry of Education (1996:40) recognized that quality education requires the availability and use of textbooks and other educational materials. Without these aids to the learning process, effective teaching and learning in the modern sense cannot take place. Suitable materials enable pupils to acquire and apply knowledge, to learn at their own pace and to assess their own progress. Phiri (2010) indicated that colleges of Education in Zambia did not have enough textbooks and other training and learning resources necessary for the moulding of teachers. The libraries in Colleges of Education are ill equipped. In most cases, the few books available are too shallow to mould a teacher's skills. Books that are found are those written by the Ministry of Education e.g. pupils books and teachers' handbooks. But books that talk about theories and approaches of teaching cannot be found in the colleges. If there are any, they are either obsolete publications or only one textbook which is not easily accessible to students. Students have to buy their own materials to produce what is demanded of them in the form of assignments. This contradicts with what Ivowi (2004) noted that to ensure that the curriculum is effectively implemented, tools and materials must be provided sufficiently.

In summary, literature discussed above has brought out some of the reasons why some lecturers are not prepared to train teachers and it has also discussed a number of challenges experienced by 
different teacher training institutions. Some of the challenges which were highlighted include caliber of students, over enrolment, lack of teaching and learning resources, non-involvement in the curriculum innovation process, inadequate staffing and ill equipped libraries.

\section{Methods of Data Collection AND Analysis}

The research design used was convergent parallel design. The researcher concurrently collected both qualitative and quantitative data, compared them, and then used the results to provide answers to the research questions.

Using purposive and simple random sampling, a total of forty nine participants were sampled and this was broken down as follows: four college administrators (vice principals) and forty five lecturers from the literacy and language education departments from four primary colleges of education.

The main tools of data collection for this study were questionnaires and interview guides. Data collected through interviews (qualitative data), was organized guided by research questions and objectives. The data was then interpreted and discussed. Objectives and their corresponding research questions formed the themes for qualitative data. Quantitative data was analyzed using the statistical package for social sciences (SPSS) to generate descriptive statistical information in form of frequencies as well as percentages.

\section{RESULTS AND DISCUSSION}

The study sought to establish literacy and language lecturers' preparedness to train teachers in literacy and language education. The findings under each objective will be dealt with separately.

\subsection{College Lecturers' Preparedness to Train Teachers in Literacy and Language Education}

The question on college lecturers' preparedness to train teachers in literacy and language education was answered using both qualitative and quantitative data. Face to face interviews with college administrators and literacy and language education lecturers were used to generate qualitative data while a questionnaire was used to generate quantitative data from the lecturers of literacy and language education. To answer the first question, qualitative data will be presented followed by quantitative data.

\subsection{College Lecturers' Preparedness to Train Teachers in Literacy and Language Education: Qualitative Data}

The findings from interviews with college administrators revealed that literacy and language lecturers were not prepared to train teachers at the time of appointment. Most lecturers had challenges interpreting the college curriculum. This was due to the qualifications the lecturers had which limited them in pedagogical knowledge and skills needed for training teachers. Some of the responses from college administrators were:

Most of the lecturers are not prepared. For some it is because of their qualifications. We expect the least qualification for a lecturer to be bachelors degree but sometimes even diploma holders are sent to colleges. The system is now porous. Anyone can become a lecturer without any recommendations from the college. But colleges no longer have the powers to control the flow of staff. (College administrator 1)

Some new lecturers find it difficult to adapt because of failure to interpret the college curriculum. Mostly those with a secondary trained background find challenges with the primary methodology. (College Administrator 2)

It takes time for the lecturers to be prepared. Mastery of the content is a challenge which most of the lecturers face. It is different from primary or secondary because a teacher works with thirty or forty minutes periods emphasizing on the same content. But with college content a lecturer is supposed to prepare for one or two hours, covering as much content as possible. (College administrator 3)

The responses revealed that most of the lecturers were not prepared to train teachers in literacy and language education. Some of the reasons included lack of right qualifications and failure to interpret the college curriculum. Other reasons included higher level content which differed with their previous experiences. 
The literacy and language lecturers who were the main source of data were asked how prepared they were to train teachers at the time of appointment. This was important since they were the trainers of teachers who were deployed into schools to teach learners. Most of the literacy and language lecturers said they were not prepared because of their previous training and experience while others stated that they were partially prepared. Few reported that they were prepared and ready to teach though with a few challenges. The following were some of the responses:

Being secondary trained, it was very difficult to adjust to primary teaching. This was because the methods and content were different from what the initial training was. Secondary teaching has a different approach to primary teaching. (Lecturer 1)

The college curriculum requires thorough preparation and using a lot of methods and strategies in order to impart the necessary skills and knowledge to the students in each and every lesson which is different from the previous experience where as a teacher one is considered to be master of everything and always at the centre. (Lecturer 2)

Initial training as a primary school teacher helped a lot because I was able to relate the way I was trained with what was expected of me. However, lack of confidence slowed down the progress because it was from teaching young ones to teaching adults. (Lecturer 3)

It took time to settle but through trial and error and consultation, we managed to pull through. (Lecturer 4)

We were prepared to train teachers because the moment we reported, we were oriented and inducted at college level as well as the departmental level. Lessons were observed from experience or long serving lecturers. Guidance was given by the Head of Department and we were free to approach any member of the section for any further guidance. We were attached to other experienced lecturers who became our mentors and they really helped us to settle. (Lecturer 5)

From the responses above, it can be argued that although all the literacy and language lecturers were initially trained as teachers, most of them said that being a college lecturer was different from being a secondary or primary school teacher. It meant adjusting to a level which required a lot of effort to be put in. They said that a lot of time was needed to fully understand the requirements of the college curriculum. This can be linked to what Kunje and Lewin (2004) found in Malawi that the majority of lecturers were either secondary school teachers who had been seconded to colleges to train primary school teachers without any further training themselves. They recommended that seconded lecturers should undergo some form of training to equip them with the different skills which should in turn be transferred to the students. This shows that although teachers from either secondary schools or primary schools become teacher educators, there is a gap between the level of learners they were handling and the new level they were appointed to train. Therefore, unpreparedness comes in because they was no training to formally prepare them as teacher educators.

\subsection{College Lecturers' Preparedness to Train Teachers in Literacy and Language Education: Quantitative Data}

The findings about the preparedness of college lecturers to train teachers in literacy and language lecturers were supported by quantitative data from the questionnaires. The questionnaires were only administered to college lecturers. In response to the statements in the questionnaire, the following data was collected:

Literacy and language lecturers were asked if they were prepared to train teachers in literacy and language education. The findings were presented in the table below.

Table1. I was adequately prepared to teach literacy and language education at college at the time of appointment

\begin{tabular}{|c|c|c|c|c|c|}
\hline \multicolumn{2}{|c|}{} & Frequency & Percent & Valid Percent & C. Percent \\
\hline \multirow{4}{*}{ Valid } & Strongly Disagree & 0 & 0 & 0 & 0 \\
\cline { 2 - 6 } & Disagree & 22 & 51.2 & 51.2 & 51.2 \\
\cline { 2 - 6 } & Agree & 16 & 37.2 & 37.2 & 88.4 \\
\cline { 2 - 6 } & Strongly agree & 5 & 11.6 & 11.6 & 100.0 \\
\cline { 2 - 6 } & Total & 43 & 100.0 & 100.0 & \\
\hline
\end{tabular}


The responses in the table above indicate that 51.2 percent of the lecturers said that they were not prepared to train teachers at the time of their appointment while 48.8 percent said that they were prepared to train teachers. This was an indication that most of the literacy and language lecturers were not prepared to train teachers at the time of appointment. This shows that although some lecturers were not prepared to train teachers, others were prepared to train teachers at the time of appointment.

The literacy and language lecturers were asked whether they received any form of induction into college teaching when they just reported for work as college lecturers. The findings were as follows;

Table2. I was inducted into college teaching upon my first appointment

\begin{tabular}{|l|l|l|l|l|l|}
\hline \multicolumn{2}{|c|}{} & Frequency & Percent & Valid Percent & Cumulative Percent \\
\hline Valid & Strongly disagree & 3 & 7.0 & 7.0 & 7.0 \\
\cline { 2 - 6 } & Disagree & 27 & 62.8 & 62.8 & 69.8 \\
\cline { 2 - 6 } & Agree & 12 & 27.9 & 27.9 & 97.7 \\
\cline { 2 - 6 } & Strongly agree & 1 & 2.3 & 2.3 & 100.0 \\
\cline { 2 - 6 } & Total & 43 & 100.0 & 100.0 & \\
\hline
\end{tabular}

Most of the literacy and language education lecturers represented by 69.8 percent said that they were not inducted into college teaching and roles when they were appointed with only 30.2 percent stating that they were inducted. This shows that majority of the lecturers were not inducted in the primary college programme. It meant that most of the lecturers found themselves in the sink or swim situation. They had to discover and learn on their own. However, one can also wonder the effect such a period had on the students. Firstly, they were not trained as college lecturers and they did not also receive any form of induction. This showed their unpreparedness to train teachers because they lacked the necessary skills and knowledge to train teachers. This lack of induction is also reported by Bunyi, Wangia, Magoma and Limboro (2011) who found out that in Kenya there was no training or induction programmes for Public Teacher Training Colleges (PTTC) lecturers who like most of the Zambian counterparts were not prepared to train teachers because they lacked the necessary teacher training knowledge. For lecturers to effectively train teachers there was need for induction and orientation upon being appointed. Most teacher educators entering the profession had not undertaken specific training, and this makes the induction phase crucial in developing understanding of their particular roles, which entails second-order teaching competences.

In order to find out more about how prepared the literacy and language lecturers were to train teachers, they were asked if at all the college offered continuous professional development to support literacy and language education lecturers. The following were the responses:

Table3. College offers Continuous Professional Development support to literacy and language education lecturers

\begin{tabular}{|l|l|l|l|l|l|}
\hline \multicolumn{2}{|c|}{} & Frequency & Percent & Valid Percent & Cumulative Percent \\
\hline Valid & Strongly disagree & 1 & 2.3 & 2.3 & 2.3 \\
\cline { 2 - 6 } & Disagree & 21 & 48.8 & 48.8 & 51.2 \\
\cline { 2 - 6 } & Agree & 21 & 48.8 & 48.8 & 100.0 \\
\cline { 2 - 6 } & Strongly agree & 0 & 0 & 0 & 100.0 \\
\cline { 2 - 6 } & Total & 43 & 100.0 & 100.0 & \\
\hline
\end{tabular}

The findings show that 51.2 percent of the lecturers stated that they were not supported by the colleges in terms of Continuous Professional Development (CDP) while 48.8 percent stated that they were supported by the college when it came to CPD.

Banja (2016) in his study stated that to overcome many of the challenges and stress faced by newly appointed teacher educators, orientation and induction as well as Continuous Professional Development was cardinal. It is therefore imperative for colleges of education to continuously hold CPD in departments or college level to update, share knowledge and experiences. This requires sensitisation which should go hand in hand with CPD/ induction policy in colleges of education. This will help to narrow the mismatch between their previous work and the new job. Through CPD and induction literacy and language lecturers will acquire the skills needed to train teachers and in due course become experts themselves as coaches. Lecturers whose initial training was weak and had no induction, found challenges and in this case may end up misleading the students who may in turn mislead the learners in schools. 
The message coming from the findings is that lecturers in primary colleges of education were themselves not adequately trained to train teachers. This explains why Mwanza (2012) found that primary school teachers were not adequately trained to teach at primary school where for instance, the medium of instruction at college was at variance with what was taking place in primary schools. Further, Lack of appropriate qualification by lecturers is worsened by the fact that teacher training strategies such as peer teacher have also been brought to question by Manchishi and Mwanza (2016) who found peer teaching to be less effective due to the fact that teacher training institutions took peer teaching as a testing instead of as a teaching/learning experience for the student teachers.

\subsection{Challenges Literacy and Language Lecturers Face when Training Teachers in Literacy And Language Education}

When asked about the challenges literacy and language education lecturers face when training lecturers, most of the administrators stated that there were a number of challenges which the colleges had been facing in connection to literacy and language education section and which the lecturers themselves face. The following were the responses;

Lecturers or colleges of education are usually left out when it comes to any changes in the school curriculum. This makes work difficult for them as they just prepare students without knowing what is obtaining on the ground. You find that new and updated materials may be sent to schools but colleges may still be using outdated materials. (Administrator 1)

The negative attitude of some lecturers is also worrying. They don't take work serious. They leave out whatever they are not comfortable with instead of consulting their colleagues. Some lecturers may have the knowhow about certain issues but fail to share with their colleagues. (Administrator 2)

Lack of seriousness makes students abandon their classes and attach themselves to other lecturers. This makes some classes to be overcrowded classrooms.

\section{(Administrator 3)}

Lecturers are encouraged to have CPDs both at college level and section level. But due to pressure of work, they fail to meet to share information in connection with their work. (Administrator 4)

The other serious issue is the caliber of students nowadays. The students in colleges fail to perform according to the expectations of the lecturers. (Administrator 5)

Literacy and language lecturers, being trainers of teachers, highlighted some of the challenges which they faced when training students in literacy and language education. The challenges included policy related and college related such as the following;

Policy issues are key to any country and for development to take place, all stakeholders must be involved at every level. We are usually left out as colleges of education when it comes to issues concerning education. Primary school teachers are trained and change the way of lesson delivery but when our students go there, they face challenges because of differences in training and implementation. As lecturers we also appear lost when students ask us. For example, the 2014 revised curriculum which was introduced to schools leaving out colleges (Lecturer 1).

We have no idea about what is going on in terms of literacy in primary schools. Students complain that when they go for school experience, they find different methods of teaching literacy from those they were trained. The picture out there is like lecturers don't train the students but the issue is they are not updated. Sometimes when there is a new programme these invited do not share with others when they come back (Lecturer 2).

Teaching and learning materials are a challenge. The college does not procure the materials to be used by both students and lecturers. The ministry usually distributes materials to primary schools leaving out colleges of education. So you find that colleges may not have materials found in schools (Lecturer 5).

High enrolment levels in colleges of education make us fail to teach literacy and language education effectively. There is no time for hands on activities because of the numbers (Lecturer 6). 
The caliber of the students leaves much to be desired. Most of the students do not perform according to the expectations. Presentation of work for most students is not at an acceptable Level (Lecturer 7).

The literacy and language section is badly hit in terms of staff. They are situations were people are transferred but never replaced. We end up being overloaded and in the end effectiveness is not there as most attend to students to fulfill their duty and not to actually teach. In some instances colleges hire teachers from secondary schools to reduce on period overload from lecturers (Lecturer 8).

The literacy and language lecturers stated that students were prepared according to what the lecturers knew. This means that there was a disconnection between the literacy and language college curriculum and school literacy curriculum. This is what Kalimaposo (2010) meant when he said that colleges of education and lecturers were not consulted in the curriculum innovation process and some lecturers indicated that they were only involved in the curriculum innovation process in the final stages to rubber stamp the programme. MOE (1977) stipulated that there should be short in-service and upgrading courses for teacher educators to ensure that they, too, keep up to date with new developments and techniques in the fields. But according to the findings, most of the literacy and language education lecturers were not conversant with revised literacy curriculum currently being used in schools. The disjuncture between teacher training and what was obtaining in schools was also reported by Manchishi and Mwanza (2013) who found that student teachers of English from the University of Zambia faced challenges to adapt to the demands of classroom teaching because the content they received during training was not aligned to what they were supposed to teach upon graduation.

In terms of negative attitudes by some lecturers to train teachers, Mwanza (2017) explains that teachers (lecturers) attitudes are very important in the success or failure of an education agenda in the school. It is therefore important in this case that college administrators study the causes of bad attitude among college lecturers and rectify the weakness for the good of quality teacher training. Teacher training requires a motivated work force that will prepare teachers in a wide range of skills and abilities. Mwanza $(2016,2017)$ advises that if teachers are supposed to be eclectic in their teaching, teacher training institutions should train them into eclectic teachers.

\section{CONCLUSION}

A number of issues were brought concerning the preparedness of college lecturers to train teachers in literacy and language education. Teacher educators are trainers of teachers and it is important to make sure that they are not only academically and professionally trained but also prepared to train teachers. The findings show that most of the literacy and language education lecturers were not prepared when they were appointed to train teachers because of a number of factors. The transition from primary or secondary teaching creates a knowledge gap thereby leading to lecturers lacking the knowledge base for teacher training. There is no training for one to become a lecturer hence the need for induction, orientation and mentoring in colleges of education which according to the findings does not take place. The literacy and language education lecturers also have little or no knowledge in the current primary schools literacy curriculum thereby creating a gap between how they train students and what students are expected to teach in primary schools. Further, teacher training is mired with challenges. The findings revealed the following as challenges; continuous changes made to the curriculum which leaves lecturers training students in outdated methodologies, lack of teaching and learning materials including non-stocking of the library with new and latest books. Other challenges include inadequate staffing in the literacy and language education department and high enrolment levels. The caliber of students who come with good grades but fail to perform according to expectations is also another challenge faced by literacy and language education lecturers.

\section{REFERENCES}

[1] Britzman, D. P. (2003). Practice makes Practice: A critical study of learning to teach (revised edition). Albany, NY: State University of New York Press.

[2] Bunyi, G.W., Wangia, J., Magoma, C.M. and Limboro, C.M. (2011). Teacher preparation and continuing professional development in Kenya. Nairobi: Kenyatta University. 
[3] Changwe, R. (2017). Effectiveness of the mathematics teacher education curriculum at the University of Zambia in preparing secondary school teachers of mathematics. Lusaka: UNZA

[4] Chella, J. (2015). Preparedness of Trainee Teachers in Initial Literacy while on School Experience in selected Primary schools in Kitwe District, Zambia. Lusaka: UNZA.

[5] Cruickshank, D., and Metcalf, K. (1990) Training within teacher preparation. In Houston,R. (Ed) Handbook of research on teacher education. New York: Macmillan

[6] European Commission. (2012b). Supporting the Teaching Professions for Better Learning Outcomes. Strasbourg, 20.11.2012. SWD (2012) 374 final.

[7] Ivowi, U.M.O. (2004). Curriculum implementation for school administration; Noah, A.O.K, shonibare, D.O. Ojo A.A and Olajuwon, T. (Eds).Curriculum implementation and professionalizing teaching in Nigeria, Lagos: central educational service.

[8] Kombe, C. (2017). Teachers' preparedness to implement the 2014 revised literacy policy in selected primary schools in Kitwe district. Unpublished masters dissertation.

[9] Kombo, D. K. and Tromp, D. L. A. (2006). Proposal and Thesis Writing: An Introduction. Nairobi: Pauline Publication Africa.

[10] Korthagen, F., Loughran, J and Russell, T. (2006). "Developing Fundamental Principles for Teacher Education Programs and Practices." Teaching and Teacher Education 22 (8): 1020-1041.

[11] Kunje ,D. and Lewin K. M. (2000) The Costs and Financing of Teacher Education in Malawi MUSTER Discussion Paper No 2, Centre for International Education, University of Sussex.

[12] Mabale, M.B. (2012). Challenges faced by lecturers in the implementation of National Certificate Vocational Curriculum at Mopani South East FET College. Unpublished.

[13] Manchishi, P. C. and Mwanza, D.S. (2016). Teacher Preparation at the University of Zambia.: Is Peer Teaching Still a Useful Strategy? International Journal of Humanities Social Sciences Educations (IJHSSE) 3 (11): $88-100$.

[14] Manchishi, P.C and Mwanza, D.S. (2013). The University of Zambia School Teaching Experience: Is It Effective? Excellence in Higher Education. 4 (2), 61-77.

[15] Ministry of Education (1992) Focus on Learning. Lusaka: Ministry of Education

[16] Ministry of Education.(1977). Educational Reforms: Proposals and recommendations. Lusaka: Government Printers.

[17] Ministry of Education. (1996). Educating our Future. Lusaka: Zambia Education Publishing House.

[18] Ministry of Education. (2013).Curriculum Framework. Lusaka: Curriculum Development Centre

[19] Mulama, S. (2006).The sexuality education needs of teacher trainees in Kenya. Downloaded on 05/08/2011 from http:www.arsrc.org.

[20] Mutemeri, J. (2013). Teaching and learning of teacher education students in South African universities with a context of quality. Cape Peninsula: University of Technology. Thesis. Unpublished.

[21] Mwanza, D.S. (2017). The Eclectic Approach to Language Teaching: Its Conceptialisation and Misconceptions. International Journal of Humanities Social Sciences and Education (IJHSSE). 4 (2): 53 67.

[22] Mwanza, D.S. (2017). Implications of Teachers' Attitudes Towards Unofficial Languages on English Language Teaching in Multilingual Zambia. Journal of Language Studies, 1 (1): 101-124.

[23] Mwanza, D.S. (2016). A Critical Reflection on Eclecticism in the Teaching of English Grammar at Selected Zambian Secondary Schools. Unpublished PhD Thesis. University of Western Cape, South Africa.

[24] Mwanza, D. S. (2012). The Language of Initial Literacy in a Cosmopolitan Environment: A Case of Cinyanja in Lusaka District. Unpublished Masters Dissertation, School of Education, University of Zambia.

[25] Ndirangu, W. C. (2013) .Effectiveness in Teaching and Learning of Kiswahili in Primary Teacher Training Colleges in Central Kenya. Kenya: Kenyatta University.

[26] Perraton, H. (2015). Teacher Education: The Role of Open and Distance Learning. London: Routledge.

[27] Ridge, E. (n.d). Communicative Language Teaching: Some Challenges for Teacher Trainers in South Africa. http:perlinguam.jpurnals.ac.zm

[28] Sinkinson, A. (1979). Teachers into lecturers: an agenda for change, teacher development, 1:1, 105, DOI: 10:1080/13664539 70020002

[29] Tambulukani G. and Bus, A. G. (2012). Linguistic diversity: A contributory factor to problems in reading in Zambian schools. Journal of Applied Linguistics: 33/2: 141-160, Oxford University Press. 
[30] UNESCO.(2011). Pre-service teacher training. Paris: UNESCO

[31] Villegas-Reimers, E., Reimers, F. (1998) The Preparation of Teachers in Latin America: Challenges and Trends. Washington, DC: Latin America and the Caribbean Regional Office. The World Bank.

\section{AUTHORS' BIOGRAPHY}

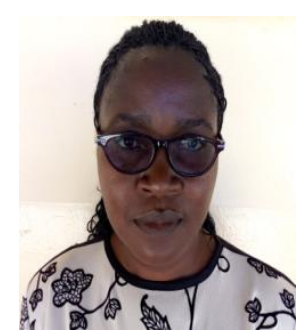

Ms. Gwen Mutolwa is a Senior Lecturer of Literacy and Language Education (LLE) at Malcolm Moffat College of Education (MMCE) in Serenje, Central Zambia. She has just completed her Master of Education in Applied Linguistics from the University of Zambia. She is a setter and an examiner of Literacy and Language Development as well as Literacy and Language Education at Teacher Education levels under the auspices of the Examinations Council of Zambia teacher education, early childhood language development and English teaching methods.

Citation: Gwen Mutolwa. "Teacher Educators' Preparedness to Train Teachers of Literacy in Selected Primary Colleges of Education in Zambia". International Journal of Humanities Social Sciences and Education (IJHSSE), vol. 6, no.5, 2019, pp. 49-59. doi: http://dx.doi.org/10.20431/2349-0381.0605005.

Copyright: () 2019 Authors. This is an open-access article distributed under the terms of the Creative Commons Attribution License, which permits unrestricted use, distribution, and reproduction in any medium, provided the original author and source are credited. 